\title{
Adam Leszczyński, Skok w nowoczesność. \\ Polityka wzrostu w krajach peryferyjnych 1943-1980, wstęp Zygmunt Bauman, Wydawnictwo Krytyki Politycznej, Instytut Studiów Politycznych PAN, Warszawa 2013, ss. 584
}

(c) $\underset{\text { BY }}{\ominus}$ DO DO: http://dx.doi.org/10.12775/KLIO.2014.017

siążka Adama Leszczyńskiego ukazuje się na rynku wydawniczym
w chwili, kiedy konieczność silniejszej integracji polskiej nauki historycznej z humanistyką na świecie jest często postulowana. Wartość recenzowanej monografii wynika z jej oryginalnej tematyki, w której znalazło się miejsce dla polskiej historii, prezentowanej jednak w szerszym kontekście europejskim oraz międzynarodowym.

Leszczyński śledzi dawne i współczesne debaty poświęcone rozwojowi gospodarczemu i zacofaniu, cytując wiele współczesnych oraz dwudziestowiecznych opracowań anglojęzycznych z dziedziny historii gospodarczej oraz historii politycznej. Prowadząc obszerną kwerendę piśmiennictwa naukowego z obszaru ekonomii i politologii, autor ukazał uniwersalność niektórych rozwiązań przyjmowanych w dwudziestym stuleciu. W swojej narracji stara się on uwypuklić ówczesną racjonalność $\mathrm{w}$ podejmowaniu kluczowych decyzji gospodarczych, z których niektóre z perspektywy czasu mogłyby się wydawać nielogiczne. Od Wielkiego Kryzysu aż po lata siedemdziesiąte, próbując wyrwać się z pułapki zacofania, wiele z ówczesnych decyzji było podejmowanych w przekonaniu o konieczności interwencjonizmu państwowego oraz planowania gospodarczego.

Większą otwartość na problemy tak zwanych krajów zacofanych, zdaniem Leszczyńskiego, zapoczątkowała dopiero druga wojna światowa, podczas której w Niemczech i USA dominowała planowa gospodarka wojenna, a przełomowy artykuł Paula Rosensteina-Rodana z 1943 roku miał stanowić fundament oraz punkt wyjścia dla toczonej później debaty. Tekst ten zawierał koncepcję przyspieszonego rozwoju zacofanych terytoriów Europy, w tym konieczności planowania, roli państwa i jego inwestycji 
w gospodarce oraz "przesunięcia” tak zwanych ludzi zbędnych ze wsi do miast. Wcześniej pomysły przyspieszonego rozwoju pojawiły się w ZSRR. Były to na przykład koncepcje Jewgienija Preobrażeńskiego, zdaniem którego chłopi powinni przyjąć na siebie ciężar industrializacji, żywiąc miasta, sprzedając żywność po zaniżonych cenach skupu. Innym z wdrażanych pomysłów była teoria Grigorija Feldmana, który uważał, że większe inwestycje w tzw. przemysł ciężki przyczynią się do wzrostu konsumpcji w ZSRR w przyszłości. Takie koncepcje, w których najważniejszą rolę odgrywało planowanie i uprzemysłowienie, a które szczegółowo analizuje w swojej książce Leszczyński, stanowiły punkt wyjścia dla wielu powojennych projektów, wdrażanych głównie w zacofanych ekonomicznie dyktaturach w różnych częściach globu.

Celem książki Leszczyńskiego jest ukazanie kontekstu historycznego dla teorii i działań podejmowanych w krajach peryferyjnych. W obliczu bezprecedensowego sukcesu gospodarczego krajów Zachodu, najpierw USA, potem Europy Zachodniej, wiele państw zacofanych musiało podporządkować swoją politykę gospodarczą interesom państw lepiej rozwiniętych. Rządzący w krajach zacofanych stawali przed trudnym wyborem: peryferia nie mogły iść prostą drogą, wypróbowaną przez centrum, ponieważ droga ta została definitywnie zamknięta. Docieramy tu do ważnego wątku stopnia niezależności krajów zacofanych. Borys Kagarlicki w książce Imperium peryferii, poświęconej modernizacji w Rosji, określa ciekawy kontekst dla tak sformułowanego problemu, pisząc:

Ideolodzy modernizacji widzą w niej coś w rodzaju wyścigu, w którym, rzecz jasna, są pierwsi i ostatni. Przypomina to zawody biegaczy albo wyścig koni na hipodromie. W tego rodzaju wyścigu zawsze możliwe jest stwierdzenie, dlaczego któryś z jego uczestników wyrwał do przodu lub pozostał w ogonie. Jednak stosunki między centrum a peryferiami kształtują się na zupełnie innych zasadach. Zasoby, których dostarczają peryferia, zapewniają przyspieszenie centrum [...]. Im aktywniejszy udział w tych „zawodach” biorą peryferia, tym bardziej zwiększa się ich zacofanie i tym bardziej sprzyja to „oderwaniu się” przez Zachód. Z drugiej strony wszystkie fazy, które przechodzi Zachód, są powtarzane przez kraje peryferii nie tyle z opóźnieniem, ile w innej formie. Innymi słowy, nie jest to sytuacja dwóch samodzielnych uczestników wyścigu, lecz raczej relacja koń-jeździec [...]. Radziecką modernizację w istocie można 
porównać do próby zrzucenia jeźdźca i kontynuowania biegu w dotychczasowym kierunku ${ }^{1}$.

Kraje zacofane z wielu przyczyn nie mogły podążyć, zdawałoby się, prostą drogą wytyczoną przez „Zachód”. Podczas gdy w połowie stulecia państwa zachodnie były już znacznie uprzemysłowione, reszta świata skazana była na zacofaną produkcję rolną oraz import przemysłowych towarów i zaawansowanej technologii. Oczywiście pewną barierą dla rozwoju były też realia polityczne zimnej wojny, które zmusiły kraje „trzeciego świata” do opowiedzenia się po jednej ze stron, a co za tym idzie - wyboru „socjalistycznego” lub „kapitalistycznego” modelu. Na komunizm można więc, nieco prowokacyjnie, spojrzeć jako na próbę zrzucenia jeźdźca przez konia biegowego. W takiej perspektywie „zimnowojenna” alternatywa w wymiarze ekonomicznym zafałszowywała rzeczywistość. Planowanie gospodarcze stanowiło de facto podstawę ekonomicznego podejścia wszędzie, gdzie myślano o rozwoju, niezależnie po której stronie ,żelaznej kurtyny” znajdował się dany kraj. Koń i jeździec brali udział w tym samym wyścigu. Zgodnie z przywołaną metaforą Kagarlickiego, również planowanie gospodarcze w komunizmie, które przyjęło swoistą, niespotykaną nigdzie dotychczas formę, było modyfikacją modernizacji dokonanej wcześniej w krajach rozwiniętych. Za przykład może posłużyć Magnitogorsk, który był przecież wzorowany na amerykańskim mieście Gary; w bolszewickiej Rosji w wielu dyskusjach doceniano Stany Zjednoczone jako najbardziej rozwiniętą cywilizację ${ }^{2}$.

Dla krajów zacofanych argumentem za obraniem innej drogi rozwoju niż potęgi gospodarcze była konieczność wykonania tytułowego „skoku w nowoczesność”, zwykle w krótkim czasie, na przykład w perspektywie

${ }^{1}$ B. Kagarlicki, Imperium peryferii. Rosja i system światowy, tłum. E. Leonkiewicz, B. Szulęcka, Warszawa 2012, s. 365.

${ }^{2}$ S. Kotkin w swojej pionierskiej pracy o Magnitogorsku pisał: „This Soviet cult of America - a young, dynamic country that appeared to have made itself - took many forms, from the worship of industrial technology to a sense among large segments of the population that they had inherited from the Americans the mantle of civilization and enlightenment, even as their envy and imitation persisted". S. Kotkin, Magnetic Mountain. Stalinism as a Civilization, Berkeley-Los Angeles 1997, s. 363. 
jednej dekady. Przynajmniej w sferze języka starano się unikać kopiowania gotowych wzorców. W wyborze ,własnej drogi” pomagał, tak w przypadku rosyjskiego komunizmu, jak i byłych kolonii europejskich, argument etyczny: „[...] sukcesu Zachodu nie tylko nie da się naśladować - bo czasy się zmieniły - ale nawet nie należy o tym myśleć, bo został osiągnięty niedopuszczalnymi z moralnego punktu widzenia metodami” - zauważa Leszczyński (s. 73). Jednocześnie w niektórych dawnych koloniach, w Chinach, ale także w państwach Europy Wschodniej, obok realizowanego „skoku w nowoczesność”, toczyła się brutalna walka o władzę, w ramach której forsowano oryginalne pomysły na wyjście z zacofania, którym jednak daleko było do rozwiązań humanitarnych. Nie wiemy, ilu gwałtownych i tragicznych w skutkach dla milionów ludzi „skoków gospodarczych” udałoby się uniknąć, gdyby nie konieczność pokonania rywali w rządach i komitetach partyjnych.

Jak już wspomniano, autor powołuje się często na ekonomistów oraz historyków, a Skok w nowoczesność jest właściwie naukową monografią z pogranicza historii gospodarczej, historii idei oraz teorii politycznej. Leszczyński używa we wstępie pojęcia „ekonomii politycznej”, którego jednak szczegółowo nie definiuje. Większego doprecyzowania we wstępie wymagałyby również pojęcia „wzrost”, „rozwój” oraz „modernizacja”. Obecność tego pierwszego słowa w tytule monografii można odczytać jako intencję autora, aby zawęzić podjętą problematykę. Użycie słowa „rozwój” zmusiłoby bowiem Leszczyńskiego do przyjęcia nieco szerszej perspektywy, która została zarysowana w rozdziale pierwszym, jednym z najlepszych w książce, stanowiącym próbę odpowiedzi na pytanie, „skąd wzięło się zacofanie?”‘ . Autor cytuje między innymi Erica Hobsbawma, który sformu-

${ }^{3}$ Ciekawy rysunek zaczerpnięty z jednej z publikacji naukowych (s. 40) mógłby być punktem wyjścia do takiej próby zdefiniowania pojęć. Ogólnie można odnieść wrażenie, że w książce brakuje wykorzystania ogromnego teoretycznego zaplecza, które znalazło się w bibliografii. Leszczyński cytuje setki opracowań, ale nie decyduje się na wybór najważniejszych teorii, które jego zdaniem stanowiłyby drogowskazy w narracji oraz podstawę dla analiz.

4 Jest tu widoczna pewna niekonsekwencja, ponieważ słowo „rozwój” jest używane często (zob. np. uwagi dotyczące użycia pojęcia „rozwój” w literaturze, s. 127-130), podczas gdy słowo „wzrost”, użyte w tytule, znika w narracji. 
łował pogląd, że pytanie o rozwój można sprowadzić do dylematu „dlaczego Szwajcaria jest bogatsza od Albanii?”:

oba kraje są podobne - małe, górzyste, pozbawione surowców naturalnych i dobrych gleb; oba także przez stulecia były bardzo biedne [...]. Odpowiedź na to pytanie wymaga przytoczenia wielu powodów - historycznych, religijnych, gospodarczych [...] (s. 46).

Ważna byłaby w recenzowanej książce również próba szerszego zdefiniowania tego, jak w rozmaitych krajach rozumiano modernizację, to znaczy: jakie właściwie działania - poza planowaniem gospodarczym wchodziły w jej zakres. Czy tylko uprzemysłowienie było świadectwem wzrostu modernizującej się w latach pięćdziesiątych i sześćdziesiątych Polski Ludowej? Obok industrializacji podejmowano przecież szereg kluczowych decyzji związanych ze „skokiem w nowoczesność” jak alfabetyzacja, organizacja służby zdrowia, a nawet wycofanie religii ze szkół czy nowoczesne prawo aborcyjne. Zdaję sobie sprawę, że tak szerokie ujęcie wymagałoby napisania odrębnej monografii poświęconej rozwiązaniom, które niekoniecznie były projektami stricte ekonomicznymi, na przykład nowym instytucjom publicznym, zmianom w demografii, diecie i wielu innym czynnikom cywilizacyjnym, które wpierw wpływały na znaczące różnice w rozwoju w XIX wieku, aby później stać się ważną składową projektów „inżynierii społecznej” w krajach zacofanych w XX wieku. Chciałbym jednak w tym miejscu wskazać na ten istotny, i poza nielicznymi wzmiankami pomijany przez Leszczyńskiego, kontekst dwudziestowiecznych „skoków w nowoczesność. Po rewolucji przemysłowej w Anglii oraz po kluczowej dla zachodniego świata diagnozie maltuzjańskiej proponowano wiele ambitnych projektów zmiany społecznej, od obowiązkowej edukacji elementarnej po eutanazję, która również przecież miała ułatwić rozwój społeczny. Nie należy ich lekceważyć, gdyż wszystkie te pomysły dotyczyły w mniejszym lub większym stopniu także strategii rozwoju gospodarczego. Wszystkie one były kontynuowane w jakiejś formie po drugiej wojnie światowej. Sztandarowym, holistycznym projektem nowoczesnej przebudowy był zakorzeniony w niemieckiej dziewiętnastowiecznej reformie rządu Bismarcka projekt „państwa opiekuńczego” 
(Sozialstaat) oraz, również mający swe korzenie w liberalnych przekonaniach XIX stulecia, brytyjski projekt „państwa dobrobytu” (welfare state) Williama Beveridge’a, czyli, jak pisał Tony Judt w Powojniu: „państwowa służba zdrowia, stosowna emerytura państwowa, zasiłki rodzinne i niemal pełne zatrudnienie”5. Postulat „państwa opiekuńczego” widoczny był na przykład w modernizacyjnej ideologii Polski Ludowej i, co więcej, został on częściowo zrealizowany, w formie powszechnego dostępu do świadczeń zdrowotnych (od lat siedemdziesiątych, po włączeniu wsi do systemu), w rozwoju szkolnictwa powszechnego i alfabetyzacji, w systemie emerytalnym oraz innych świadczeniach pracowniczych.

W kontekście znaczenia państwa opiekuńczego dla koncepcji wzrostu i planowania gospodarczego warto nawiązać do polemiki ekonomisty Herberta Frankela z diagnozami zacofania postawionymi z początkiem lat pięćdziesiątych przez ekspertów ONZ prezentowanej w Skoku w nowoczesność (s. 145-149). Frankel twierdził, że PKB niekoniecznie zwiększa dobrobyt obywateli, ponieważ jest pojęciem szerszym, wykraczającym poza statystyki wzrostu gospodarczego i dochodu. Rozwój i dobrobyt był więc od początków dwudziestowiecznego planowania czymś zasadniczo odmiennym od wzrostu gospodarczego i z tej różnicy zdawano sobie sprawę. W pierwszych planach gospodarczych „skok w nowoczesność” starano się wykonywać, wdrażając forsowną industrializację, co działo się jednak kosztem konsumpcji. Swoistym buforem w tak niekorzystnej sytuacji bytowej ludności krajów zacofanych, wdrażanym wraz z industrializacją lub tuż po niej, miały być właśnie elementy państwa opiekuńczego.

Jest truizmem, że Polska była krajem zacofanym od samych narodzin koncepcji zacofania, to jest od czasów ekspansji nowoczesnego kapitalizmu. Temu położonemu na peryferiach modernizującej się Europy krajowi Leszczyński poświęca obszerne fragmenty (w tym cały jeden rozdział) swojej książki. Autor słusznie podkreśla, że w polskich zmaganiach z niedorozwojem nie było nic wyjątkowego. Wartość Skoku w nowoczesność wynika z ukazania owej przeciętnej Polski jako środkowoeuropejskiego

5 T. Judt, Powojnie. Historia Europy od roku 1945, tłum. R. Bartołd, Poznań 2008, s. 97. Szerzej na temat europejskiego państwa opiekuńczego/dobrobytu zob.: ibidem, s. 93-100, 426-441. 
kraju rolniczego, zacofanego już przed drugą wojną światową, burzonego i grabionego, pozbawionego pomocy zagranicznej, ale jednak nie tak biednego jak na przykład Chiny czy niektóre zamorskie kolonie Europy. W historii dwudziestowiecznej Polski znacząca była kontynuacja pewnej strategii rozwojowej. Jak wskazuje Leszczyński, w Drugiej Rzeczypospolitej „planizm polski” wiązał się z silnym przywiązaniem do państwa i nacjonalizmem gospodarczym, obecnymi zarówno na lewej, jak i prawej stronie sceny politycznej. Wojna nie przerwała tej tradycji, w resorcie gospodarki mieliśmy do czynienia z ciągłością ideową, a także, jak zwraca uwagę autor, do pewnego stopnia z ciągłością personalną. Trzeba jednak podkreślić, że kontynuacja ta sprowadzała się jednak głównie do samej idei planowania. W innych partiach książki autor pisze o niewątpliwych ideologicznych szaleństwach polskich komunistycznych planistów. W przeciwieństwie do realiów przedwojennej kapitalistycznej Polski, w stalinizmie produkcja nie była motywowana zyskiem, lecz strachem. Niskiej jakości produkcja przemysłowa tylko w znikomym stopniu uwzględniała popyt. Natomiast, porównując kraj z innymi państwami środkowoeuropejskimi, do specyfiki cechującej Polskę Ludową należy zaliczyć niewątpliwie uniknięcie przymusu kolektywizacji. Jego przyczyn Leszczyński dopatruje się w wizycie Gomułki w ZSRR w 1934 roku, kiedy przyszly przywódca komunistyczny miał możność zapoznania się ze skutkami nadmiernego przymusu oraz terroru.

Jak już wspomniałem, uzmysłowienie czytelnikowi ekonomicznej racjonalności, która leżała u podłoża niektórych projektów modernizacyjnych, takich jak pierwsza „pięciolatka” w ZSRR czy plan sześcioletni w Polsce Ludowej, stanowi największą wartość tej książki. Leszczyński umiejętnie unika prezentyzmu, wskazując, w jak niekiedy trudnym położeniu były kraje zacofane i jak niewielkie pole do manewru miały, aby zmienić stan, w którym się znajdowały. U podłoża tych wszystkich, jak się miało okazać po latach, z reguły nietrafionych oraz zwykle niehumanitarnych projektów, leżało przekonanie o konieczności planowania oraz, z nielicznymi wyjątkami, o konieczności uprzemysłowienia. Koszt gwałtownych zmian miały ponieść grupy dotychczas uprzywilejowane (faktycznie wyróżnione lub figurujące jako takie jedynie w propagandowym przekazie). $\mathrm{Z}$ powodu naturalnej szczupłości miejskich zasobów w rolniczych krajach zacofanych wkrótce miało się okazać, że za cały projekt nowoczesności mie- 
li zapłacić głównie chłopi. Tą koniecznością należy tłumaczyć w komunizmie mnogość projektów dążących do dyscyplinowania wsi, poczynając od dostaw obowiązkowych, przez dyktowanie cen skupu po zakładanie spółdzielni. Na czas trwania skoku w nowoczesność całe społeczeństwo miało „Zacisnąć pasa”, tak, aby szybciej dogonić mityczny Zachód (w Europie Wschodniej) lub dawnych kolonizatorów (w krajach Afryki, Azji i Ameryki Południowej). W zamian za wyrzeczenia rządzący kreślili wizję świetlanej przeszłości, w której najlepsze rozwiązania z krajów wysoko rozwiniętych spotkałyby się z wartościową lokalną specyfiką.

Pewne uogólnienia, charakteryzowane w książce podobieństwa, jak model rozwoju fikcyjnej „Rurytanii” w zakończeniu Skoku w nowoczesność, nie powinny nam przesłonić istotnych różnic. We wstępie Leszczyński nawiązuje do teorii narracyjności Haydena White’a, pisząc, że ton jego monografii historycznej nadaje ironia:

Trudno bowiem o większe nagromadzenie dobrych intencji i ambitnych planów ulepszania świata, które wyradzały się w swoje przeciwieństwo

- argumentuje (s. 41). Stwierdzenie to jest tylko częściowo słuszne; dałoby się zapewne utrzymać w przypadkach polityki Nkrumaha, Gomułki, Gierka lub Nehru, jak jednak odpowiedzieć na pytanie, czy Stalin, Mao oraz inni brutalni dyktatorzy mieli dobre intencje? Jeśli już odwołać się do koncepcji White'a, tonem opowieści w niektórych partiach recenzowanej książki jest raczej tragedia ${ }^{6}$. Inaczej mówiąc, autor wielokrotnie skupia się na skutkach masowych eksperymentów, nieskrywanego cynizmu, racjonalnego (z punktu widzenia dyktatorów i kolonizatorów) gospodarowania zdobytymi zasobami, pragmatycznego okrucieństwa, doraźnych działań decydentów, charakteryzowanych jako „osiadłych” lub „wędrownych bandytów" - by odwołać się do przywoływanej w książce teorii Mancura Olsona. W innych partiach książki narracja jest rzeczywiście nacechowana ironią, szczególnie tam, gdzie zostały ukazane postawy i decyzje takich afrykańskich przywódców, jak Kwame Nkrumah i Julius Nyerere, jednak

${ }^{6}$ Zob.: H. White, Poetyka pisarstwa historycznego, red. E. Domańska, M. Wilczyński, Kraków 2000 (rozdział „Tekst historiograficzny jako artefakt literacki”). 
i tu aktualne pozostaje pytanie o wyrachowaną, systemową korupcję, która od począ̧ może też w Skoku w nowoczesność dostrzec niebagatelne różnice, które dotyczą modeli rozwojowych „twardych” dyktatur, takich jak Chiny czy Rosja, przeciwstawione "miękkim” dyktaturom, takim jak Polska. Co więcej, widoczne są nawet różnice w polityce najważniejszych dyktatorów - podczas gdy w myśleniu leżącym u podstaw planowania gospodarczego w ZSRR możemy znaleźć elementy racjonalnej ekonomicznej kalkulacji, trudno za taką uznać działania Mao Zedonga, który uważał, że sama polityka jest wystarczającą siłą zdolną wykreować spodziewaną modernizację. Najbardziej rzucające się w oczy były oczywiście różnice między komunistycznym a kapitalistycznym wariantem rozwoju. Nacjonalistyczni modernizatorzy w Japonii oraz Korei wybrali wariant „kapitalistyczny”, oparty na sprawnie zorganizowanej armii, biurokracji, subordynacji i tradycji firm rodzinnych. W tych krajach przemysł i planowanie, w odróżnieniu od modelu komunistycznego, bazowały na istnieniu zdrowej konkurencji. Leszczyński wymienia szereg powodów, dla których „azjatyckie smoki” - Korea i Tajwan oraz Japonia - osiągnęły to, czego nie udało się innym zacofanym krajom Afryki, części Azji i Ameryki Południowej (s. 449-455), z czego najbardziej oczywiste wydają się czynniki zachowania prywatnej przedsiębiorczości, ale także wybranych tradycji kulturowych.

W końcowych partiach książi w przekonujący sposób ukazane zostały źródła liberalnego myślenia o gospodarce, które uzyskało przewagę w doktrynie ekonomicznej lat osiemdziesiątych (s. 457-488). Liberalne poglądy - wpierw Friedriecha von Hayeka, później Miltona Friedmana oraz nie mniej opiniotwórcze opinie Edmunda Phelpsa zasadzały się na przekonaniu, że „naturalne w gospodarce jest to, o czym decyduje rynek bez interwencji państwa” (s. 470). Założeniu temu towarzyszyły koncepcje teoretyczne np. o "naturalnej stopie bezrobocia” Friedmana czy teoria Roberta Lucasa, zgodnie z którą wyższe bezrobocie było skutkiem "nieprzewidywalnej polityki państwa” oraz teoria Roberta Barro dotycząca niemożności zwiększenia popytu przez państwo. We wszystkich tych teoriach podważano, uważane powszechnie do końca lat sześćdziesiątych $\mathrm{XX}$ wieku za niepodważalne, teorie interwencjonizmu państwowego, planowania gospodarczego, państwa opiekuńczego oraz takie szczegółowe 
rozwiązania, jak stymulacja popytu, kumulacja kapitału oraz kontrola poziomu inflacji.

Ambitne założenia przyświecające historykom należy chwalić i popierać. Książka Leszczyńskiego dotyczy kluczowego problemu z historii XX wieku, bez próby uchwycenia którego trudno jest współcześnie dyskutować o tym stuleciu. Jak w każdym takim ambitnym przedsięwzięciu, rodzą się rozmaite dodatkowe pytania oraz kilka uwag krytycznych dotyczących konstrukcji pracy ${ }^{7}$. Obszerna, zaopatrzona w bogatą bibliografię monografia Leszczyńskiego pozostawia pewien niedosyt, co należy potraktować w tym przypadku jako zaletę, a nie wadę - niewątpliwie wywołuje dyskusję, wprowadza twórczy ferment, rozszerza pole widzenia historyków dziejów najnowszych, często skoncentrowanych na wąskich dziedzinach badawczych. Poniżej pragnąłbym postawić kilka pytań, które nasunęły mi się podczas lektury i które, moim zdaniem, wymagałyby w przyszłości dyskusji. Podstawowe z nich, które nie pada w książce, to pytanie o definicje: co właściwie rozumiano przez „kraj rozwinięty”, a ściślej - gdzie leżałaby granica między takimi krajami a tymi zacofanymi w drugiej połowie XX wieku? Tematyką książki jest niewątpliwie wymagający wizji i odwagi „skok w nowoczesność, wypadkowa teorii akademickich, ideologii (kapitalizm, komunizm) oraz podejmowanych, nieraz rozpaczliwych, prób planowania gospodarczego. Odnosi się wrażenie, że Leszczyński świadomie zatrzymuje się wpół drogi oraz nie formułuje fundamentalnego pytania: czy można powiedzieć, że u źródeł klęski dwudziestowiecznego planowania leżały nie tyle błędne założenia, ile dwudziestowieczne dyktatury? W tym

7 W książce znalazły się pewne powtórzenia oraz niepotrzebne dygresje, zacierające sens wywodu. Zbędne wydają się np. opisy handlu niewolnikami i codziennego życia na plantacjach, które niewiele wnoszą do teorii rozwoju (s. 78-83), podobnie nieistotne dla zrozumienia polityki wzrostu w ZSRR wydają się fragmenty o złych warunkach życia w Magnitogorsku (s. 165-170). W tym ostatnim przypadku lepiej byłoby postawić pytanie, w jakim stopniu Magnitogorsk, miasto powstałe od nowa, było kopią rozwiązań kapitalistycznej Ameryki, a w jakim stopniu było czymś zupełnie innym. W rozdziale o ZSSR („Kolonia wewnętrzna”) nie widzę związku między omawianym przez autora niemieckim planowaniem (s. 179-181) a polityką NEP, którą autor charakteryzuje chwilę później. Podobnie rozważania niemieckich myślicieli z XIX wieku we fragmencie o Ameryce Łacińskiej również wydają się mieć akurat w tym miejscu niewielkie uzasadnienie (s. 401$-405)$. 
kontekście lektura partii poświęconych Chinom i polityce Mao Zedonga nasuwa kolejne pytanie o granice: $\mathrm{w}$ którym momencie kończy się polityka wzrostu, a zaczyna wyrachowana gra o władzę oraz wojna domowa prowadzona pod hasłami przebudowy (czy casus Kambodży w lat siedemdziesiątych to jeszcze polityka wzrostu czy już tylko ludobójstwo)? W generalnie udanym rozdziale „Święto poety” o Chińskiej Republice Ludowej autor nie stawia kropki na „i”, nie podejmuje się próby wyjaśnienia paradoksu, jak w biednym kraju, podatnym na terror polityczny i ekstremizm dyktatury udało się w latach „skoków” utrzymać wysoki wzrost PKB (ludobójstwo eliminujące problem przeludnienia?, niewolnicza praca?, wzrost między kolejnymi „skokami”?, tradycje kulturowe ciężkiej pracy?). Te kluczowe pytania w znacznym stopniu dotyczą też wczesnego i ,środkowego" etapu historii ZSRR. Czy w kontekście historii ChRL historia ZSRR mogła się potoczyć inaczej? Rodzą się następne pytania o wzajemne relacje między demokracją, dyktaturą a rozwojem - w tym pytanie, czy demokracje rzeczywiście sprzyjały rozwojowi krajów zacofanych, czy była to przypadkowa zbieżność lub zależność była bardziej złożona (o tym, że sprzyjać rozwojowi miały na wczesnym etapie dyktatury, pisał na przykład David Apter w 1965 roku w pracy The Politics of Modernization) oraz nie mniej istotne pytanie, czy wzrost gospodarczy oraz rozwój społeczny sprzyjały ekspansji oraz stabilności systemów demokratycznych? Problem ten badał Adam Przeworski, podkreślając przy okazji, że demokracje, jeszcze w latach siedemdziesiątych XX wieku były wciąż w zdecydowanej mniejszości ${ }^{8}$.

Leszczyński swój przegląd „krajów zacofanych” kończy na początku lat osiemdziesiątych XX wieku, co było decyzją słuszną, ponieważ inne ustalenie cezur znacznie zwiększyłoby objętość tej, i tak już obszernej, pracy. Z drugiej strony, granica ta pozostawia pewien niedosyt i w wielu wypadkach nie pozwala odpowiedzieć na ważne pytanie, jakie czynniki decydowały, że niektórym krajom udało się rozpocząć pogoń za krajami rozwiniętymi? Czy była to tylko opozycja komunizm-kapitalizm? Czy były

${ }^{8}$ Do prac, w których chyba najpełniej zostały przedstawione wyniki pionierskich badań politologiczno-historycznych, należy: Democracy and Development. Political Institutions and Well-Being in the World, 1950-1990, ed. A. Przeworski et al., Cambridge 2000. 
to uwarunkowania lokalne i kulturowe? Czy może były to czynniki uniwersalne, związane np. ze wzmiankowaną wyżej dychotomią demokracja-dyktatura? Na marginesie porażki „socjalistycznej” mutacji polityki wzrostu, po lekturze rozdziału „Planizm polski” ważne wydaje się także pytanie, co stało się w latach osiemdziesiątych w Polsce? To znaczy, co sprawiło, że elity „Solidarności” straciły zaufanie do modelu socjalizmu, państwa opiekuńczego i idei równości, od których nie odżegnywano się przecież jeszcze w postulatach sierpniowych. Wydaje się konieczne zapytać, czy porażkę idei socjalizmu w Europie Środkowo-Wschodniej należy tłumaczyć tylko niewydolnością gospodarczą późnych krajów komunistycznych, czy może popularyzacją w latach osiemdziesiątych XX wieku teorii von Hayeka na Zachodzie, do którego przecież coraz bardziej aspirowano. To jednak pytania badawcze na przyszłość, które wykraczają poza ramy recenzowanej, niewątpliwie cennej, monografii Adama Leszczyńskiego.

Piotr Perkowski (Gdańsk) 